\title{
Primary Thrombophilia XIV: Worldwide Identification of Sticky Platelet Syndrome
}

\author{
María Fernanda Vallejo-Villalobos, $\mathrm{PhD}^{1}$ Gisela Berenice Gomez-Cruz, MD²,3 \\ Yahveth Cantero-Fortiz, MD ${ }^{2,4}$ Juan Carlos Olivares-Gazca, MD ${ }^{2,5}$ Mauricio Olivares-Gazca, MD ${ }^{2,5}$ \\ Iván Murrieta-Alvarez, MD2,3 Virginia Reyes-Nuñez, $\mathrm{PhD}^{5,6}$ \\ Guillermo J. Ruiz-Argüelles, MD, FRCP (Glasg), MACP, DSc (hon) ${ }^{2,5}$
}

${ }^{1}$ Hospital Christus Muguerza Betania de Puebla, Puebla, México

${ }^{2}$ Centro de Hematología y Medicina Interna de Puebla, Puebla, México

${ }^{3}$ School of Medicine, Benemérita Universidad Autónoma de Puebla, Puebla, México

${ }^{4}$ School of Medicine, Universidad de las Américas Puebla, Puebla, México

${ }^{5}$ School of Medicine, Universidad Popular Autónoma del Estado de Puebla, Puebla, México

${ }^{6}$ Laboratorios Clínicos de Puebla, Puebla, México

Semin Thromb Hemost 2019;45:423-428.

Sticky platelet syndrome (SPS) is a prothrombotic platelet disorder characterized by increased in vitro platelet aggregation after activation with low concentrations of adenosine diphosphate and/or epinephrine. ${ }^{1-67}$ Recently, Favaloro and Lippi $^{66}$ provided a commentary on the increasing number of papers published on SPS along the historical timeline, since its initial description in 1988, ${ }^{3}$ and in response an update review was also published in this journal. ${ }^{67}$ As noted in both reports, ${ }^{66,67}$ the condition is not recognized by all workers involved in the study for treatment of thrombophilic conditions. One reason to explain the fact that some researchers recognize SPS as a genuine thrombophilic condition whilst other do not is that not everybody employs the same criteria to define the condition. We and others, ${ }^{11,53}$ attempting to standardize its investigation, employ the criteria originally described by Mammen et al $^{3}$ to define SPS, and accordingly, our group has been able to show that around 15\% of Mexican mestizo persons within the general normal population meet the criteria to identify them as bearers of SPS and that this figure goes up to $60 \%$ in Mexican mestizo patients with a clinical marker of inherited thrombophilia. Accordingly, we have been able to gather prospectively a group of 165 Mexican mestizo patients with SPS, 121 of whom (66.7\%) display another thrombophilic condition in addition to SPS. Employing the database PubMed, we similarly looked for all entries using the term "sticky platelet," either in the title and/or in the body of the abstract. The salient features of each publication were then further analyzed. The initial search identified a total of 108 papers. Forty-one of them included the combination of words but did not actually describe SPS and were accordingly dis-

published online April 30, 2019
Address for correspondence Guillermo J. Ruiz-Argüelles, MD, FRCP (Glasg), MACP, Dsc (hon), Centro de Hematología y Medicina Interna de Puebla, 8B Sur 3710, 72530 Puebla, Mexico (e-mail: gruiz1@clinicaruiz.com).

carded; 24 papers comprised reviews about SPS and 43 papers described either cases or series of patients; these latter 43 papers were further analyzed. The first paper describing patients with SPS was identified to be published in 1988, and was authored by Mammen et al. $^{3}$ Since then and until February 2019, as noted above, 67 papers were identified. ${ }^{1-67}$ - Fig. 1 depicts the number of papers published as a cumulative timeline, whereas - Fig. 2 depicts the countries in which these papers were published. It is interesting to note that the country with the largest number of papers published on SPS is the United States with a total of 14 , followed by Slovakia with 12 , Germany with 8, and México with 6, whereas Hungary, Turkey, Russia, and New Zealand had only 1 publication each. What is also interesting is the absence of reports from most other geographies (-Fig. 2).

A total of 1,783 patients with SPS have been described and published in these 30 years (1988-2019) of reports. The rate of description of these cases has increased in the last 10 years (-Fig. 1). The most number of cases have been identified and published in Slovakia $(n=845)$, followed by the United States $(n=451)$, México $(n=322)$, Germany $(n=88)$, and Russia $(n=70)$. The thromboses identified in these patients were both venous and arterial; in some patients SPS was identified together with another thrombophilic condition, either inherited or acquired. - Table 1 gathers the salient information from all these publications. Most patients (72\%) were treated with aspirin and/or other antiplatelet drugs, whereas $27 \%$ were given oral anticoagulants or heparin.

According to several publications, SPS is thought, at least by several investigators, to be the most common inherited
Copyright (c 2019 by Thieme Medical Publishers, Inc., 333 Seventh Avenue, New York, NY 10001, USA. Tel: +1(212) 584-4662.
DOI https://doi.org/ 10.1055/s-0039-1688498. ISSN 0094-6176.
Thrombosis and Cancer-Part I; Guest Editors: Hau C. Kwaan, MD, PhD, and Paul F. Lindholm, MD. 


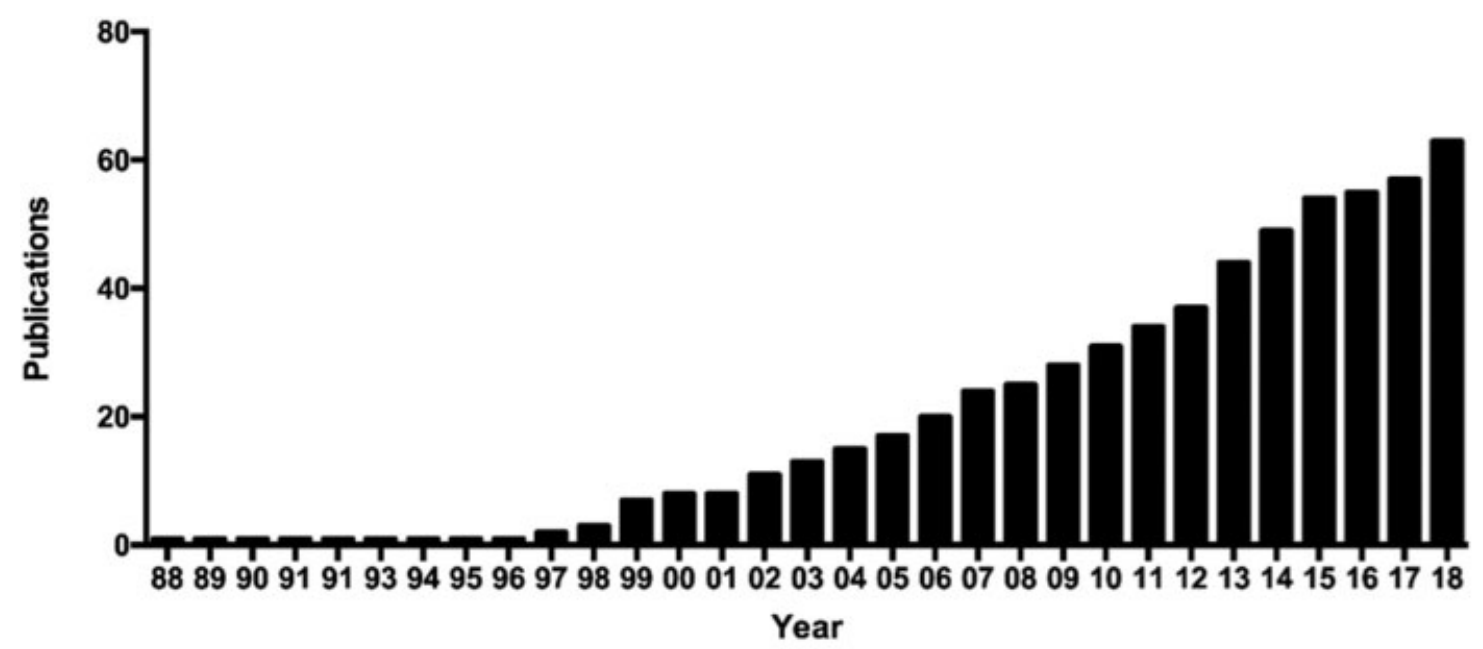

Fig. 1 Cumulative frequency distribution curve along time of papers published on the sticky platelet syndrome between 1988 and 2018 inclusive.

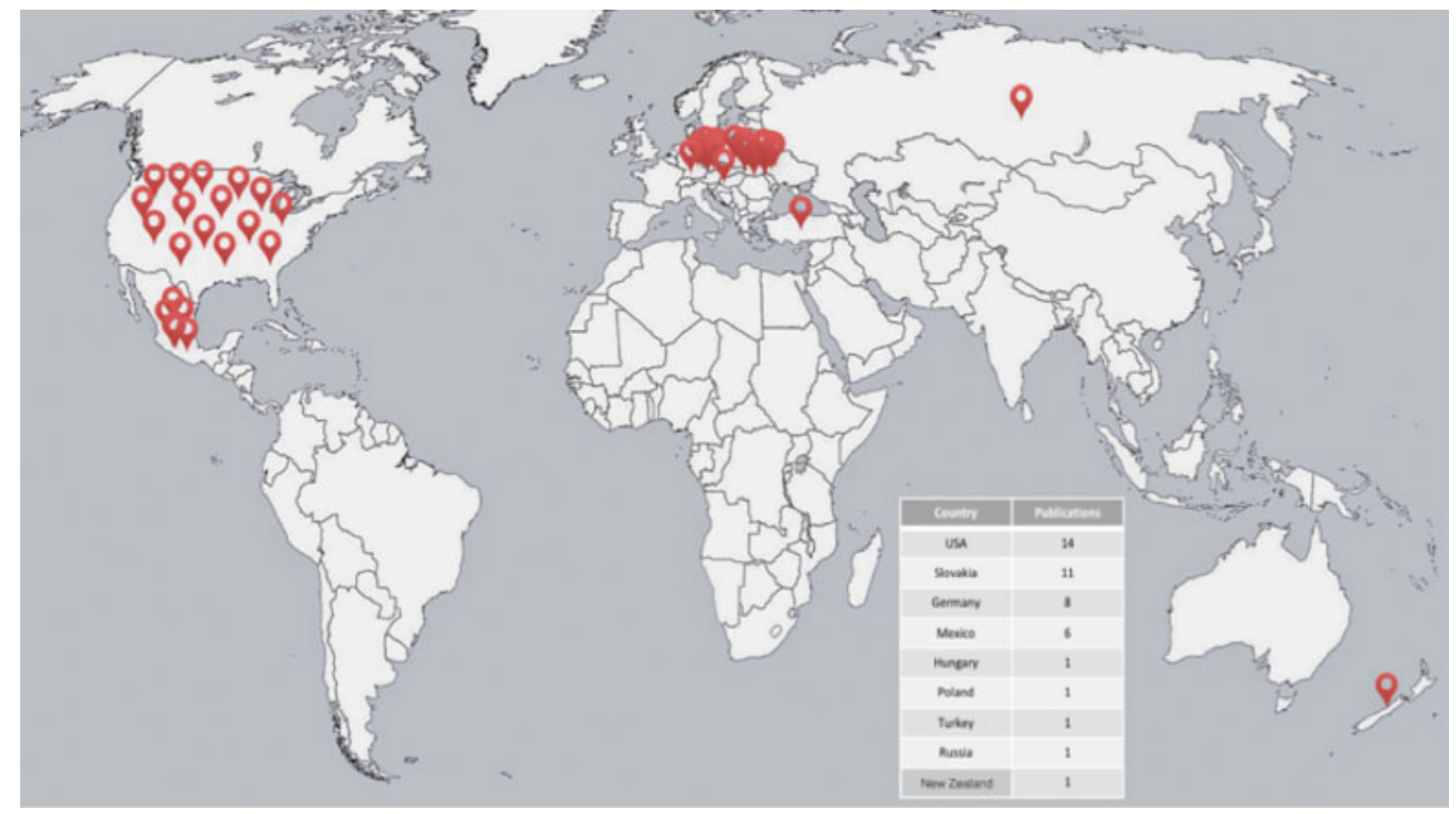

Fig. 2 Countries in which the sticky platelet syndrome has been described between 1988 and 2018 inclusive.

prothrombotic platelet defect and thus likely to be of the greatest clinical importance. ${ }^{49}$ The recognition of SPS as a genuine entity has prompted the development of both promoters and opponents to the concept. ${ }^{66,67}$ Up to now, the lack of a definite molecular basis for the condition has been a major obstacle for its acceptance by many as a distinct entity and several skeptical scientists remain reluctant to consider this disease as a true distinct clinicopathological entity. ${ }^{49,66,67}$ On the other hand, unlike plasma-based hemostasis research work, the study of SPS requires fresh patient material and highly meticulous sample collection and handling; as a consequence, the patients under investigation require blood collection at the time of investigation, and then platelet function testing needs to be performed immediately afterwards by experienced personnel. Some hemostasis experts still consider the aberrant platelet aggregation responses seen in this condition as laboratory artifacts $^{49}$; however, SPS seems to be building up an increasing belief base, if we accept that the increasing publication rate on the topic (66; - Fig. 1), coupled with the additional information presented here, represents increasing acceptance of SPS as a prothrombotic condition. Taking into account the number of inhabitants in each of the countries which have reported cases of the SPS, it is clear that the countries which have made the most contributions on SPS per number of inhabitants are Slovakia and México; this finding reflects mainly the interest in the condition of groups of scientists living in these two countries, headed by 
Table 1 Salient features of the patients with the sticky platelet syndrome who have been described in different countries between 1988 and 2018 inclusive

\begin{tabular}{|c|c|c|c|c|c|}
\hline Author & Country & Year & Cases & Location of thrombosis & Treatment \\
\hline Mammen et $\mathrm{al}^{3}$ & United States & 1988 & $?$ & $\mathrm{Ml}$ & Aspirin \\
\hline Berg-Dammer et al $^{4}$ & Germany & 1997 & 2 & $\begin{array}{l}\text { Superior sagittal sinus/middle } \\
\text { cerebral artery/left subclavian/ } \\
\text { left vertebral artery }\end{array}$ & $\begin{array}{l}\text { Heparin/aspirin/catheter/ } \\
\text { thrombolysis }\end{array}$ \\
\hline Baker and Bick $^{6}$ & United States & 1999 & 153 & DVT/stroke/MI/retinal vein & Aspirin \\
\hline Chaturvedi and Dzieczkowski $^{8}$ & United States & 1999 & 1 & Acute stroke & Heparin/warfarin \\
\hline Bick $^{10}$ & United States & 2000 & 21 & Recurrent miscarriage & Aspirin \\
\hline Weber et al $^{12}$ & Germany & 2002 & 34 & $\begin{array}{l}\text { DVT/retinal vein thrombosis/ } \\
\text { portal vein thrombosis/ } \\
\text { pulmonary embolism }\end{array}$ & Heparin/aspirin \\
\hline Frenkel and Mammen ${ }^{15}$ & United States & 2003 & 200 & Acute stroke, DVT & Aspirin $81 \mathrm{mg} / \mathrm{d}$ \\
\hline Lewerenz et al $^{17}$ & Germany & 2004 & 1 & Acute stroke/MI & Aspirin \\
\hline Kahles et $\mathrm{al}^{21}$ & Germany & 2006 & 1 & $\begin{array}{l}\text { Acute myocardial infarction/ } \\
\text { pulmonary embolism }\end{array}$ & $\begin{array}{l}\text { Abciximab/stent/antiplatelet } \\
\text { therapy/t-PA/heparin }\end{array}$ \\
\hline Kubisz et $\mathrm{al}^{20}$ & Slovakia & 2006 & 128 & $\begin{array}{l}\text { Acute stroke/MI/DVT/ } \\
\text { recurrent miscarriage }\end{array}$ & - \\
\hline Fodor et $\mathrm{al}^{23}$ & Hungary & 2007 & 1 & Left internal carotid artery & Aspirin $300 \mathrm{mg} / \mathrm{d}$ \\
\hline Mühlfeld et $\mathrm{al}^{25}$ & United States & 2007 & 3 & $\begin{array}{l}\text { Renal allograft rejection/ } \\
\text { colonic microinfarctions/ } \\
\text { pulmonary embolism/DVT }\end{array}$ & Heparin/aspirin \\
\hline Randhawa and Van Stavern ${ }^{26}$ & New Zealand & 2007 & 1 & Ischemic optic neuropathy & Aspirin $81 \mathrm{mg} / \mathrm{d}$ \\
\hline Ruiz-Argüelles et al $^{24}$ & Mexico & 2007 & 46 & $\begin{array}{l}\text { Thrombosis at younger than } \\
40 / \text { recurrent thrombosis/ } \\
\text { thrombosis in unusual sites }\end{array}$ & Aspirin \\
\hline El-Amm et $\mathrm{al}^{27}$ & United States & 2008 & 3 & Renal allograft rejection & Aspirin \\
\hline Mears and Van Stavern 29 & United States & 2009 & 1 & Ischemic optic neuropathy & Aspirin $81 \mathrm{mg} / \mathrm{d}$ \\
\hline Sand et $\mathrm{al}^{28}$ & Germany & 2009 & 1 & $\begin{array}{l}\text { Cutaneous microembolism on } \\
\text { fingers }\end{array}$ & Heparin/aspirin \\
\hline Bojalian et $\mathrm{al}^{3}$ & United States & 2010 & 1 & $\begin{array}{l}\text { Popliteal artery/renal and } \\
\text { splenic infarction/left axillar } \\
\text { artery/left subclavian artery/ } \\
\text { left internal jugular vein }\end{array}$ & Heparin/embolectomy/aspirin \\
\hline 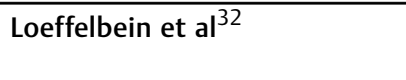 & Germany & 2010 & 1 & $\begin{array}{l}\text { Venous and arterial flap } \\
\text { thrombosis }\end{array}$ & Aspirin \\
\hline Alexandra et $\mathrm{al}^{34}$ & United States & 2011 & 1 & Retinal vein & Aspirin \\
\hline Gehoff et $\mathrm{al}^{36}$ & Germany & 2011 & 1 & Acute stroke & Aspirin \\
\hline Rac et $\mathrm{al}^{35}$ & United States & 2011 & 1 & Recurrent miscarriage & Aspirin $325 \mathrm{mg} / \mathrm{d}$ \\
\hline Kotuličová et al ${ }^{40}$ & Slovakia & 2012 & 77 & $\begin{array}{l}\text { Pulmonary embolism/DVT/MI/ } \\
\text { acute stroke }\end{array}$ & - \\
\hline Kubisz et $a^{38}$ & Slovakia & 2012 & 9 & $\begin{array}{l}2 \mathrm{DVT} / 4 \text { arterial (acute stroke, } \\
\mathrm{MI} \text {, arterial thrombosis)/3 both }\end{array}$ & - \\
\hline Sokol et $\mathrm{al}^{39}$ & Slovakia & 2012 & 27 & Recurrent miscarriage & Aspirin \\
\hline 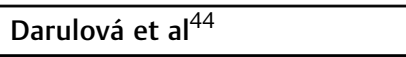 & United States & 2013 & 1 & Pulmonary embolism & Alteplase/heparin \\
\hline Ruiz-Argüelles et al ${ }^{47}$ & Mexico & 2013 & 100 & $\begin{array}{l}\text { Thrombosis at younger than } \\
40 / \text { recurrent thrombosis/ } \\
\text { thrombosis in unusual sites }\end{array}$ & Aspirin \\
\hline Šimonová et al ${ }^{46}$ & Slovakia & 2013 & 9 & $\begin{array}{l}\text { Cerebral venous thrombosis/ } \\
\text { DVT/pulmonary embolism/ } \\
\text { acute stroke/MI }\end{array}$ & Heparin/aspirin \\
\hline Tekgündüz et al ${ }^{42}$ & Turkey & 2013 & 6 & History of thrombosis & Aspirin $100 \mathrm{mg} / \mathrm{d}$ \\
\hline Vasil'ev et al ${ }^{41}$ & Russia & 2013 & 70 & Thrombosis & Heparin/aspirin \\
\hline
\end{tabular}


Table 1 (Continued)

\begin{tabular}{|c|c|c|c|c|c|}
\hline Author & Country & Year & Cases & Location of thrombosis & Treatment \\
\hline Castillo-Martínez et al ${ }^{52}$ & Mexico & 2014 & 1 & Cutaneous limb veins & Aspirin $81 \mathrm{mg} / \mathrm{d}$ \\
\hline Hayes et al $^{51}$ & United States & 2014 & 64 & Acute stroke/DVT/MI & Aspirin \\
\hline Kubisz ${ }^{48}$ & Slovakia & 2014 & 71 & Acute stroke & - \\
\hline Ruiz-Arguelles ${ }^{50}$ & Mexico & 2014 & 95 & $\begin{array}{l}\text { Thrombosis at younger than } \\
40 / \text { recurrent thrombosis/ } \\
\text { thrombosis in unusual sites }\end{array}$ & Aspirin \\
\hline Alsheekh et al $^{55}$ & United States & 2015 & 1 & Carotid artery & Abciximab/thrombectomy \\
\hline Sokol et $\mathrm{al}^{53}$ & Slovakia & 2015 & 23 & Recurrent miscarriage & Aspirin \\
\hline Sokol et $\mathrm{al}^{56}$ & Slovakia & 2015 & 20 & Recurrent miscarriage & Aspirin \\
\hline Yagmur et $\mathrm{al}^{54}$ & Germany & 2015 & 48 & $\begin{array}{l}\text { TIA/ DVT/pulmonary embo- } \\
\text { lism/renal infarction }\end{array}$ & Heparin/aspirin \\
\hline Ruiz-Delgado et al $^{60}$ & Mexico & 2017 & 77 & Recurrent miscarriage & Aspirin \\
\hline Škereňová et al ${ }^{63}$ & Slovakia & 2018 & 37 & Recurrent miscarriage & Aspirin \\
\hline Sokol et al ${ }^{65}$ & Slovakia & 2018 & 84 & DVT & Aspirin \\
\hline Sokol et al ${ }^{62}$ & Slovakia & 2018 & 360 & $\begin{array}{l}\text { DVT/pulmonary embolism/MI/ } \\
\text { miscarriage/migraine }\end{array}$ & Aspirin 325 mg/d \\
\hline Solis-Jimenez et al ${ }^{61}$ & Mexico & 2018 & 1 & $\begin{array}{l}\text { Renal allograft rejection (renal } \\
\text { infarction) }\end{array}$ & Nephrectomy/aspirin \\
\hline
\end{tabular}

Abbreviations: DVT, deep vein thrombosis; MI, myocardial infarction; t-PA, tissue plasminogen activator.

professors Peter Kubisz in Slovakia and Guillermo RuizArgüelles in México. ${ }^{49}$ We hope that the presentation of this information will result in the development of additional interest in other investigators who could eventually contribute to the better understanding and acceptance of the syndrome, its pathophysiology and treatment, with the goal of helping patients afflicted by thrombophilia, which is currently one of the leading causes of death in developed societies.

\section{Conflicts of Interest}

The authors disclose no conflicts of interest.

\section{References}

1 Press M, Hartop PJ, Hawkey C. Proceedings: the correction of essential fatty acid deficiency and 'sticky' platelets in man by the cutaneous administration of sunflower seed oil. Clin Sci Mol Med 1974;46(02):13P

2 Weston MJ, Langley PG, Williams R. Proceedings: defective platelet function with deficiency of 'sticky platelets' in fulminant hepatic failure. Gut 1975;16(05):405

3 Mammen EF, Barnhart MI, Selik NR, Gilroy J, Klepach GL. "Sticky platelet syndrome": a congenital platelet abnormality predisposing to thrombosis? Folia Haematol Int Mag Klin Morphol Blutforsch 1988;115(03):361-365

4 Berg-Dammer E, Henkes H, Trobisch H, Kühne D. Sticky platelet syndrome: a cause of neurovascular thrombosis and thromboembolism. Interv Neuroradiol 1997;3(02):145-154

5 Chaturvedi S, Dzieczkowski J. Multiple hemostatic abnormalities in young adults with activated protein $C$ resistance and cerebral ischemia. J Neurol Sci 1998;159(02):209-212

6 Baker WFJJr, Bick RL. Treatment of hereditary and acquired thrombophilic disorders. Semin Thromb Hemost 1999;25(04):387-406

7 Mammen EF. Sticky platelet syndrome. Semin Thromb Hemost 1999;25(04):361-365
8 Chaturvedi S, Dzieczkowski JS. Protein S deficiency, activated protein $C$ resistance and sticky platelet syndrome in a young woman with bilateral strokes. Cerebrovasc Dis 1999;9(02): 127-130

9 Bick RL, Rice J. Long-term outpatient dalteparin (fragmin) therapy for arterial and venous thrombosis: efficacy and safety-a preliminary report. Clin Appl Thromb Hemost 1999;5(Suppl 1): S67-S71

10 Bick RL; DRW Metroplex Recurrent Miscarriage Syndrome Cooperative Group. Recurrent miscarriage syndrome due to blood coagulation protein/platelet defects: prevalence, treatment and outcome results. Clin Appl Thromb Hemost 2000;6(03):115-125

11 Ruiz-Argüelles GJ, López-Martínez B, Cruz-Cruz D, Esparza-Silva L, Reyes-Aulis MB. Primary thrombophilia in Mexico III: a prospective study of the sticky platelet syndrome. Clin Appl Thromb Hemost 2002;8(03):273-277

12 Weber M, Gerdsen F, Gutensohn K, Schoder V, Eifrig B, Hossfeld DK. Enhanced platelet aggregation with TRAP- 6 and collagen in platelet aggregometry in patients with venous thromboembolism. Thromb Res 2002;107(06):325-328

13 Ruiz-Argüelles GJ, Ruiz-Delgado GJ, López-Martínez B. The sticky platelet syndrome: a frequent but unrecognized cause of thrombophilia [in Spanish]. Rev Invest Clin 2002;54(05):394-396

14 Bick RL. Prothrombin G20210A mutation, antithrombin, heparin cofactor II, protein C, and protein S defects. Hematol Oncol Clin North Am 2003;17(01):9-36

15 Frenkel EP, Mammen EF. Sticky platelet syndrome and thrombocythemia. Hematol Oncol Clin North Am 2003;17(01):63-83

16 Lazo-Langner A. Sticky platelet syndrome [in Spanish]. Rev Invest Clin 2004;56(01):103-104, author reply 105

17 Lewerenz V, Burchardt T, Büchau A, Ruzicka T, Megahed M. Livedoid vasculopathy with heterozygous factor $\mathrm{V}$ Leiden mutation and sticky platelet syndrome [in German]. Hautarzt 2004;55 (04):379-381

18 Bick RL, Hoppensteadt D. Recurrent miscarriage syndrome and infertility due to blood coagulation protein/platelet defects: a review and update. Clin Appl Thromb Hemost 2005;11(01): $1-13$ 
19 Ruiz-Argüelles GJ, López-Martínez B, Valdés-Tapia P, GómezRangel JD, Reyes-Núñez V, Garcés-Eisele J. Primary thrombophilia in Mexico. V. A comprehensive prospective study indicates that most cases are multifactorial. Am J Hematol 2005;78(01):21-26

20 Kubisz P, Ivankov J, Holly P, Stasko JN, Musiał J. The glycoprotein IIIa PL(A1/A2) polymorphism-a defect responsible for the sticky platelet syndrome? Clin Appl Thromb Hemost 2006;12(01):117-119

21 Kahles H, Trobisch H, Kehren H. Disseminated coronary occlusions and massive pulmonary embolism in a 40-year-old woman [in German]. Dtsch Med Wochenschr 2006;131(13):672-675

22 Andersen J. Sticky platelet syndrome. Clin Adv Hematol Oncol 2006;4(06):432-434

23 Fodor M, Facskó A, Berényi E, Sziklai I, Berta A, Pfliegler G. Transient visual loss triggered by scuba diving in a patient with a petrous epidermoid and combined thrombotic risk factors. Pathophysiol Haemost Thromb 2007;36(06):311-314

24 Ruiz-Argüelles GJ, González-Carrillo ML, Estrada-Gómez R, Valdés-Tapia P, Parra-Ortega I, Porras-Juárez A. Primary thrombophilia in México. VI: lack of statistical association among the inherited thrombophilic conditions [in Spanish]. Gac Med Mex 2007;143(04):317-322

25 Mühlfeld AS, Ketteler M, Schwamborn K, et al. Sticky platelet syndrome: an underrecognized cause of graft dysfunction and thromboembolic complications in renal transplant recipients. Am J Transplant 2007;7(07):1865-1868

26 Randhawa S, Van Stavern GP. Sticky platelet syndrome and anterior ischaemic optic neuropathy. Clin Exp Ophthalmol 2007;35(08):779-781

27 El-Amm J-M, Andersen J, Gruber SA. Sticky platelet syndrome: a manageable risk factor for posttransplant thromboembolic events. Am J Transplant 2008;8(02):465

28 Sand M, Mann B, Bechara FG, Sand D. Sticky platelet syndrome type II presenting with arterial microemboli in the fingers. Thromb Res 2009;124(02):244

29 Mears KA, Van Stavern GP. Bilateral simultaneous anterior ischaemic optic neuropathy associated with sticky platelet syndrome. $\mathrm{Br}$ J Ophthalmol 2009;93(07):885-886, 913

30 Konecny F. Inherited trombophilic states and pulmonary embolism. J Res Med Sci 2009;14(01):43-56

31 Kubisz P, Bartosová L, Ivanková J, et al. Is Gas6 protein associated with sticky platelet syndrome? Clin Appl Thromb Hemost 2010; 16(06):701-704

32 Loeffelbein DJ, Baumann CM, Mücke T, Wolff K-D, Hölzle F, Kesting MR. Sticky platelet syndrome as a possible cause for free flap failure-a case report. Microsurgery 2010;30(06):466-468

33 Bojalian MO, Akingba AG, Andersen JC, et al. Sticky platelet syndrome: an unusual presentation of arterial ischemia. Ann Vasc Surg 2010;24(05):691.e1-691.e6

34 Alexandra AO, Drenser KA. Hypercoagulable state in a patient with a retinal vein occlusion. Retin Cases Brief Rep 2011;5(01): 76-78

35 Rac MWF, Minns Crawford N, Worley KC. Extensive thrombosis and first-trimester pregnancy loss caused by sticky platelet syndrome. Obstet Gynecol 2011;117(2, Pt 2):501-503

36 Gehoff A, Kluge JG, Gehoff P, et al. Recurrent strokes under anticoagulation therapy: sticky platelet syndrome combined with a patent foramen ovale. J Cardiovasc Dis Res 2011;2(01):68-70

37 Staško J, Bartošová L, Mýtnik M, Kubisz P. Are the platelets activated in sticky platelet syndrome? Thromb Res 2011;128 (01):96-97

38 Kubisz P, Ivanková J, Škereňová M, Staško J, Hollý P. The prevalence of the platelet glycoprotein VI polymorphisms in patients with sticky platelet syndrome and ischemic stroke. Hematology 2012; 17(06):355-362

39 Sokol J, Biringer K, Skerenova M, et al. Platelet aggregation abnormalities in patients with fetal losses: the GP6 gene polymorphism. Fertil Steril 2012;98(05):1170-1174
40 Kotuličová D, Chudý P, Škereňová M, Ivanková J, Dobrotová M, Kubisz P. Variability of GP6 gene in patients with sticky platelet syndrome and deep venous thrombosis and/or pulmonary embolism. Blood Coagul Fibrinolysis 2012;23(06):543-547

41 Vasil'ev SA, Vinogradov VL, Gemdzhian EG, Orel EB, Shevelev AA, Margolin OV. Experience with outpatient treatment for thromboses and thrombophilias [in Russian]. Ter Arkh 2013;85(12):47-50

42 Tekgündüz E, Demir M, Akyol Erikçi A, Akpınar S, Oztürk E, Kırkızlar O. Sticky platelet syndrome in patients with uninduced venous thrombosis. Turk J Haematol 2013;30(01):48-52

43 Kubisz P, Stasko J, Holly P. Sticky platelet syndrome. Semin Thromb Hemost 2013;39(06):674-683

44 Darulová S, Samoš M, Sokol J, et al. Sticky platelets syndrome in a young patient with massive pulmonary embolism. Am J Case Rep 2013;14:169-172

45 Moncada B, Ruíz-Arguelles GJ, Castillo-Martínez C. The sticky platelet syndrome. Hematology 2013;18(04):230-232

46 Šimonová R, Bartosová L, Chudy P, et al. Nine kindreds of familial sticky platelet syndrome phenotype. Clin Appl Thromb Hemost 2013;19(04):395-401

47 Ruiz-Argüelles GJ, Garcés-Eisele J, Camacho-Alarcón C, et al. Primary thrombophilia in Mexico IX: the glycoprotein IIIa PLA1/A2 polymorphism is not associated with the sticky platelet syndrome phenotype. Clin Appl Thromb Hemost 2013;19(06):689-692

48 Kubisz P. Response to "Comment on sticky platelet syndrome". Semin Thromb Hemost 2014;40(02):274

49 Kubisz P, Ruiz-Argüelles GJ, Stasko J, Holly P, Ruiz-Delgado GJ. Sticky platelet syndrome: history and future perspectives. Semin Thromb Hemost 2014;40(05):526-534

50 Ruiz-Arguelles GJ. Comment on sticky platelet syndrome. Semin Thromb Hemost 2014;40(02):273

51 Hayes C, Kitahara S, Tcherniantchouk O. Decreased threshold of aggregation to low-dose epinephrine is evidence of platelet hyperaggregability in patients with thrombosis. Hematol Rep 2014;6(03):5326

52 Castillo-Martínez C, Moncada B, Valdés-Rodríguez R, González FJ. Livedoid vasculopathy (LV) associated with sticky platelets syndrome type 3 (SPS type 3) and enhanced activity of plasminogen activator inhibitor (PAI-1) anomalies. Int J Dermatol 2014;53(12):1495-1497

53 Sokol J, Biringer K, Skerenova M, Stasko J, Kubisz P, Danko J. Different models of inheritance in selected genes in patients with sticky platelet syndrome and fetal loss. Semin Thromb Hemost 2015;41(03):330-335

54 Yagmur E, Frank RD, Neulen J, Floege J, Mühlfeld AS. Platelet hyperaggregability is highly prevalent in patients with chronic kidney disease: an underestimated risk indicator of thromboembolic events. Clin Appl Thromb Hemost 2015;21(02):132-138

55 Alsheekh AA, Puggioni A, Hingorani AP, Marks N, Ascher E. The sticky platelet syndrome during carotid endarterectomy. Ann Vasc Surg 2015;29(06):1317.e9-1317.e11

56 Sokol J, Skerenova M, Biringer K, Lasabova Z, StaskoJ, Kubisz P. Genetic variations of the GP6 regulatory region in patients with sticky platelet syndrome and miscarriage. Expert Rev Hematol 2015;8(06):863-868

57 Velázquez-Sánchez-de-Cima S, Zamora-Ortiz G, HernándezReyes J, et al. Primary thrombophilia in México X: a prospective study of the treatment of the sticky platelet syndrome. Clin Appl Thromb Hemost 2015;21(01):91-95

58 Kubisz P, Stanciakova L, Stasko J, et al. Sticky platelet syndrome: an important cause of life-threatening thrombotic complications. Expert Rev Hematol 2016;9(01):21-35

59 Sokol J, Skerenova M, Jedinakova Z, et al. Progress in the understanding of sticky platelet syndrome. Semin Thromb Hemost 2017;43(01):8-13

60 Ruiz-Delgado GJ, Cantero-Fortiz Y, Mendez-Huerta MA, et al. Primary thrombophilia in Mexico XII: miscarriages are more frequent in people with sticky platelet syndrome. Turk J Haematol 2017;34 (03):239-243 
61 Solis-Jimenez F, Hinojosa-Heredia H, García-Covarrubias L, SotoAbraham V, Valdez-Ortiz R. Sticky platelet syndrome: an unrecognized cause of acute thrombosis and graft loss. Case Rep Nephrol 2018;2018:3174897

62 Sokol J, Skerenova M, Ivankova J, Simurda T, Stasko J. Association of genetic variability in selected genes in patients with deep vein thrombosis and platelet hyperaggregability. Clin Appl Thromb Hemost 2018;24(07):1027-1032

63 Škereňová M, Sokol J, Biringer K, et al. GP6 haplotype of missense variants is associated with sticky platelet syndrome manifested by fetal loss. Clin Appl Thromb Hemost 2018;24(01):63-69
64 Salvagno GL, Pavan C, Lippi G. Rare thrombophilic conditions. Ann Transl Med 2018;6(17):342

65 Sokol J, Skerenova M, Biringer K, Simurda T, Kubisz P, Stasko J. Glycoprotein VI gene variants affect pregnancy loss in patients with platelet hyperaggregability. Clin Appl Thromb Hemost 2018 (e-pub ahead of print). doi:10.1177/1076029618802358

66 Favaloro EJ, Lippi G. Commentary: controversies in thrombosis and hemostasis part 2-does sticky platelet syndrome exist? Semin Thromb Hemost 2019;45(01):69-72

67 Kubisz P, Holly P, Stasko J. Sticky platelet syndrome: 35 years of growing evidence. Semin Thromb Hemost 2019;45(01):61-68 